\title{
Propozycja modyfikacji metody miseczkowania AEG oceny tłoczności blach
}

\author{
Łukasz Kuczek DD, Wacław Muzykiewicz (D), \\ Marcin Mroczkowski (D, Marcin Wieczorek
}

AGH Akademia Górniczo-Hutnicza, Wydział Metali Nieżelaznych, Kraków

\begin{abstract}
Streszczenie: Wartość granicznego stopnia (lub współczynnika) wytłaczania określa się na podstawie próby tłoczności Swifta lub metody uproszczonej - miseczkowania AEG. Jednakże wyniki uzyskane tymi metodami mogą się istotnie różnić. Liczba trzech punktów pomiarowych (średnic krążków) w metodzie AEG bywa niewystarczająca. W pracy zaproponowano modyfikację tej metody polegającą na zastosowaniu większej liczby punktów pomiarowych, zarówno w przypadku maksymalnej siły wytłaczania jak i siły zrywającej. Analizie poddano również inne niż liniowa funkcje aproksymacji (potęgową, wykładniczą). Przy większej liczbie punktów stwierdzono krzywoliniowy charakter zmiany maksymalnej wartości siły wytłaczania w funkcji stopnia wytłaczania $K_{1}$, a także spadek wartości siły zrywającej wraz ze wzrostem średnicy krążka. Stwierdzono, że dla wyznaczenia granicznego stopnia wytłaczania za pomocą zmodyfikowanej metody miseczkowania AEG optymalny jest opis zmienności siły maksymalnej funkcją potęgową na podstawie trzech reprezentatywnych punktów pomiarowych, a siły zrywającej - funkcją liniową na podstawie przynajmniej dwóch punktów. Pozwoliło to na uzyskanie wyników porównywalnych z otrzymanymi za pomocą próby Swifta.
\end{abstract}

Słowa kluczowe: tłoczenie blach, graniczny stopień wytłaczania, metoda miseczkowania AEG, próba tłoczności metodą Swifta

\section{A PROPOSAL OF MODIFICATION OF THE AEG CUPPING TEST FOR THE ASSESSMENT OF SHEET METAL DRAWABILITY}

\begin{abstract}
The limiting drawing ratio is determined in the Swift deep drawing cup test or the AEG cupping method. However, the results obtained with the two methods may differ significantly. The total number of three measurement points (blank diameters) in the AEG method is insufficient. The paper proposes a modification of this method by using a larger number of measuring points, both for the maximum drawing force and the fracture force. Other, than linear, types of approximation functions were also analyzed (power, exponential function). With a greater number of points, the curvilinear character of the change in the maximum value of the drawing force as a function of the drawing ratio $K_{1}$ was found, as well as the decrease in the fracture force value with the increase of the blank diameter. It was found that for the determination of the limiting drawing ratio by the modified AEG cupping method, the optimum is the description of the maximum force variation with a power function based on three representative measurement points, and the fracture force with a linear function based on at least two points. This made it possible to obtain results comparable to those obtained with the Swift cup test.
\end{abstract}

Keywords: deep drawing, limiting drawing ratio, AEG cupping test, Swift deep drawing test

https://doi.org/10.7494/978-83-66727-48-9_6 


\section{Wprowadzenie}

Kształtowanie plastyczne wyrobów powłokowych jest powszechnie stosowane w wielu obszarach gospodarki, między innymi przy produkcji komponentów dla przemysłu samochodowego, lotniczego, stoczniowego, w produkcji puszek czy też sprzętu gospodarstwa domowego. Polega ono na plastycznym odkształcaniu z blachy lub folii wyrobów o dowolnym kształcie bez utraty stateczności materiału, jego spójności czy przekroczenia wytrzymałości wytłoczki poza obszar odkształceń plastycznych. Z procesami kształtowania plastycznego wyrobów powłokowych wiąże się tłoczność blach. Nie jest to swoista cecha materiału, lecz parametr silnie zależny od właściwości samego materiału oraz warunków procesu kształtowania w danej operacji technologicznej (Marciniak 1989, Muzykiewicz i in. 2006, Reddy i in. 2020a). Termin „tłoczność” można więc rozumieć jako zdolność materiału (blachy, folii) do znoszenia dużych odkształceń plastycznych i łatwość przyjmowania żądanego kształtu w określonej operacji tłoczenia (Muzykiewicz 2013, Spišák i in. 2016, Nghishiyeleke i in. 2018, Reddy i in. 2020a). Oznacza to, że - w zależności od stanu naprężenia i odkształcenia podczas kształtowania blach - materiał może charakteryzować się różną podatnością na tłoczenie.

Jednym z najważniejszych parametrów procesu kształtowania wyrobów powłokowych jest najniższa dopuszczalna wartość współczynnika wytłaczania $m_{1 g r}$, od której zależy na przykład liczba operacji koniecznych do wykonania gotowego wyrobu. Ma na nią wpływ wiele czynników, między innymi parametry procesu kształtowania, jak również zachowanie się blachy podczas odkształcania, w tym stopień umacniania się materiału (Kandil 2003, Singh i Agnihotri 2015). Współczynnik wytłaczania jest jedną z miar stopnia odkształcenia przy ciągnieniu przedmiotów cylindrycznych i definiuje się go jako stosunek średnicy wytłoczki do średnicy półwyrobu (krążka). Jednakże ze względu na wygodę oraz łatwość określania wartości maksymalnych często stosuje się tzw. stopień wytłaczania $K_{1}$, który jest odwrotnością współczynnika wytłaczania $m_{1}\left(K_{1}=1 / m_{1}\right)$.

Graniczna wartość stopnia wytłaczania $K_{1 g r}$ wynika, między innymi, z wartości sił występujących podczas procesu ciągnienia w zależności od stosunku średnicy krążka $D$ do średnicy cylindrycznej wytłoczki $d$ (rys. 1). Przy założeniu, że średnica wytłoczki jest stała $(d=$ const), zarówno siła początku plastycznego kształtowania kołnierza wytłoczki $F_{k}^{p l}$, jak i siła maksymalna $F_{k}^{\max }$ rosną wraz ze wzrostem średnicy krążka. Jednocześnie przyjmuje się, że wartości siły początku odkształcania plastycznego denka wytłoczki $F_{d}^{p l}$ oraz siły zrywającej $F_{z r}$ są stałe i nie zależą od wartości średnicy zastosowanego krążka (Erbel i in. 1986). Oznacza to, że przy pewnej granicznej wartości stosunku $D / d$ siła tłoczenia osiąga wartość, przy której następuje oderwanie dna wytłoczki. Limituje to możliwość uzyskania w jednej operacji wytłoczki o określonej średnicy i wysokości. 


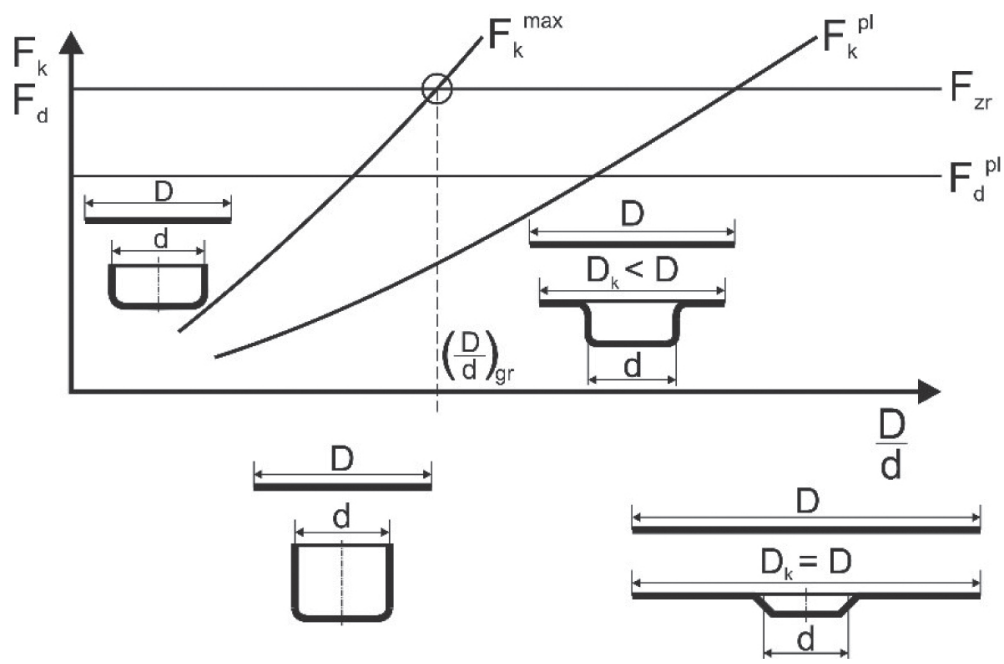

Rys. 1. Przebieg sił występujących w procesie wytłaczania w funkcji $D / d$ dla $d=$ const Źródło: na podstawie Erbel i in. (1986)

Kwestia granicznej wartości stopnia wytłaczania jest częstym tematem poruszanym przy omawianiu podatności blachy lub folii do tłoczenia (Muzykiewicz i in. 2006, Chen i in. 2011, Wang i in. 2011, Muzykiewicz 2013, Kumar i Reddy 2014, Spisak i in. 2016, Nghishiyeleke i in. 2018, Reddy i in. 2020a, Reddy i in. 2020b). Wartość teoretyczna granicznego stopnia wytłaczania $K_{1 \text { teor }}$ w małym stopniu zależy od rodzaju materiału i wynosi 2,72 ( $m_{1 \text { teor }}$ ) (Marciniak 1961, Morawiecki i in. 1986, Youssef i in. 2011). W praktyce jednak, ze względu na występujące tarcie na powierzchni kontakut krążka z narzędziami oraz zginanie i rozginanie materiału na krawędziach narzędzi, wyznaczone wartości graniczne różnią się od teoretycznej. Rzeczywiste graniczne wartości stopnia wytłaczania są przeważnie niższe od teoretycznej i nie przekraczają 2,25-2,50 (Morawiecki i in. 1986, Muzykiewicz i in. 2006, Chen i in. 2011, Wang i in. 2011, Youssef i in. 2011, Kumar i Reddy 2014, Nghishiyeleke i in. 2018, Reddy i in. 2020b). Ponadto, przy tej samej grubości blachy i tych samych warunkach procesu tłoczenia, wartość $K_{1 g r}$ jest różna dla różnych materiałów (Kumar i Reddy 2014, Kumar 2020). Co więcej, w przypadku blach bimetalowych pojawia się różnica w wartościach granicznych stopnia wytłaczania, w zależności od materiału będącego w kontakcie z matrycą (Muzykiewicz i Rękas 2007).

Często stosowaną metodą określania wartości granicznych stopnia wytłaczania jest próba tłoczności Swifta. Generalnie polega ona na tłoczeniu serii krążków aż do momentu, gdy przy danej wartości średnicy pojawi się oderwanie denka wytłoczki. Na jej podstawie uzyskuje się największą średnicę krążka $D_{\max }$, poniżej której, podczas wytłaczania, w cylindrycznym kubku nie powinno się pojawić pękanie obwodowe ścianki (Swift 1952, Wang i in. 2011, Bruschi i in. 2014, Reddy i in. 2020a). Jest to jednak 
próba czasochłonna, wymagająca wykonania krążków o średnicach nieznacznie się różniących, a co za tym idzie - z dużą precyzją wymiarową. Możliwe jest określenie przybliżonych wartości $K_{1 g r}$ na podstawie tzw. metody miseczkowania AEG (Fisher 1927, Morawiecki i in. 1986), w literaturze znanej również jako Rapid Determination Method of limiting drawing ratio (RDM) (Reddy i in. 2014). Według założeń z rysunku 1 możliwe jest określenie przybliżonej wartości stopnia wytłaczania na podstawie próby tłoczenia tylko trzech krążków. Ich średnice dobiera się w taki sposób, aby wytłaczanie dwóch z nich zakończyło się powodzeniem przy możliwie znaczącej różnicy wartości sił wytłaczania. Trzeci krążek powinien być na tyle duży, aby podczas tłoczenia nastąpiło oderwanie denka. Wartości maksymalne sił wytłaczania aproksymuje się liniowo i ekstrapoluje do wartości siły zrywającej (z założenia stałej dla danego materiału, grubości blachy i ustalonej średnicy wytłoczki $d=$ const). Punkt przecięcia wykresów maksymalnej siły wytłaczania i siły zrywającej, rzutowany na oś odciętych, daje wartość granicznego stopnia wytłaczania $K_{1 g r}$ (rys. 2).

Charakter zmiany maksymalnej siły wytłaczania w funkcji średnicy krążka (przy ustalonych pozostałych warunkach tłoczenia) może jednak odbiegać od linii prostej. W konsekwencji może to być powodem przeszacowania wartości stopnia wytłaczania, a co za tym idzie - możliwości pękania wytłoczek przy teoretycznie bezpiecznych jego wartościach.

W pracy poddano analizie wpływ liczby punktów aproksymacji (zarówno maksymalnych sił wytłaczania, jak i sił zrywających) na dokładność wyników metody miseczkowania AEG w stosunku do metody Swifta. Badania przeprowadzono na blachach ze stopu aluminium EN AW-1050A w stanie H14 o trzech różnych grubościach $(0,5 \mathrm{~mm}$, $0,8 \mathrm{~mm}$ i $1,0 \mathrm{~mm}$ ) za pomocą uniwersalnej maszyny do badania blach i taśm firmy Erichsen (model 142-40). Analizowano zarówno wpływ liczby punktów pomiarowych, jak i rodzaju stosowanej funkcji aproksymacji wyników (liniowa, krzywoliniowa) na graniczną wartość stopnia wytłaczania $K_{1 g r}$ (oraz współczynnika wytłaczania $m_{1 g r}$ ). W wyniku tych badań zaproponowano modyfikację standardowej metody miseczkowania AEG, powodującą większą zbieżność wyników z wartościami uzyskanymi za pomocą próby tłoczności Swifta, przy nieznacznym zwiększeniu liczby próbek i czasu pracy.

\section{Metodyka badań}

W pierwszej kolejności dokładne wartości granicznego stopnia wytłaczania $K_{1 g r}$ (oraz współczynnika wytłaczania $m_{1 g r}$ ) określono na podstawie próby tłoczności Swifta wg wytycznych zawartych w pracy Turno (1971) oraz zaleceń INOP (INOP-Z/201-12-78). Ich wartości przybliżone wyznaczono za pomocą metody miseczkowania AEG, standardowej oraz z różną liczbą punktów pomiarowych i funkcjami aproksymacji siły maksymalnej tłoczenia innymi niż liniowa. Próby przeprowadzano na tym samym zestawie 
narzędzi (tab. 1), z użyciem smaru grafitowego od strony matrycy. Proces tłoczenia prowadzono z prędkością stempla około $8 \cdot 10^{-5} \mathrm{~m} / \mathrm{s}(5 \mathrm{~mm} / \mathrm{min})$. Podczas prób rejestrowano wartości siły tłoczenia w funkcji drogi stempla, na podstawie których określono wartości maksymalnych sił wytłaczania oraz sił zrywających. Siła docisku była określona dla danej średnicy krążka na podstawie zależności (1) (Romanowski 1976, Erbel i in. 1986):

$$
F_{d}=A_{d} \cdot q=\frac{\pi}{4}\left[D^{2}-\left(d_{m}+2 r_{m}\right)^{2}\right] \cdot q
$$

gdzie:

$A_{d}-$ początkowa powierzchnia docisku,

$q$ - nacisk jednostkowy dociskacza, dla aluminium $q=0,7-1,2 \mathrm{MPa}$,

$D$ - średnica krążka,

$d_{m}$ - średnica otworu matrycy,

$r_{m}$ - promień zaokrąglenia krawędzi matrycy.

Tabela 1

Wymiary narzędzi stosowanych w próbie w zależności od grubości blachy

\begin{tabular}{|c|c|c|c|c|c|c|}
\cline { 2 - 7 } \multicolumn{1}{c|}{} & \multicolumn{9}{c|}{ Grubość blachy } \\
\cline { 2 - 7 } & \multicolumn{2}{c|}{$g=1,0 \mathrm{~mm}$} & \multicolumn{2}{c|}{$g=0,8 \mathrm{~mm}$} & \multicolumn{2}{c|}{$g=0,5 \mathrm{~mm}$} \\
\cline { 2 - 7 } & $d[\mathrm{~mm}]$ & $r[\mathrm{~mm}]$ & $d[\mathrm{~mm}]$ & $r[\mathrm{~mm}]$ & $d[\mathrm{~mm}]$ & $r[\mathrm{~mm}]$ \\
\hline Stempel & 32,0 & 4,5 & 32,0 & 4,5 & 32,0 & 4,5 \\
\hline Matryca & 35,6 & 13,0 & 34,6 & 9,0 & 33,7 & 6,0 \\
\hline
\end{tabular}

Zarówno w przypadku metody miseczkowania AEG, jak i Swifta na jeden punkt pomiarowy przypadało po pięć pomiarów (krążków o danej średnicy), na podstawie których obliczano średnie wartości siły maksymalnej tłoczenia oraz siły zrywającej w zależności od średnicy krążka.

Próbę tłoczności Swifta przeprowadzono na krążkach o średnicy z zakresu od $50 \mathrm{~mm}$ do $60 \mathrm{~mm}$, z krokiem zmienności o mniejszej wartości niż wynikający z zaleceń INOP i wynoszącym $1 \mathrm{~mm}$. Na podstawie badania wyznaczono maksymalne wartości średnic krążków, poniżej których pękanie wytłoczek nie następowało. Pozwoliło to na określenie minimalnej dopuszczalnej wartości współczynnika wytłaczania $m_{1 g r}=d / D_{\max }$ oraz maksymalnej dopuszczalnej wartości stopnia wytłaczania $K_{1 g r}=D_{\text {max }} / d$. Do obliczeń przyjęto średnicę stempla jako średnicę wytłoczki $d$.

$\mathrm{Na}$ rysunku 2 przedstawiono schemat metody określania przybliżonej wartości współczynnika wytłaczania za pomocą standardowej próby miseczkowania AEG, przy użyciu trzech krążków o różnych średnicach (Fisher 1927, Morawiecki i in. 1986, Reddy i in. 2014). 


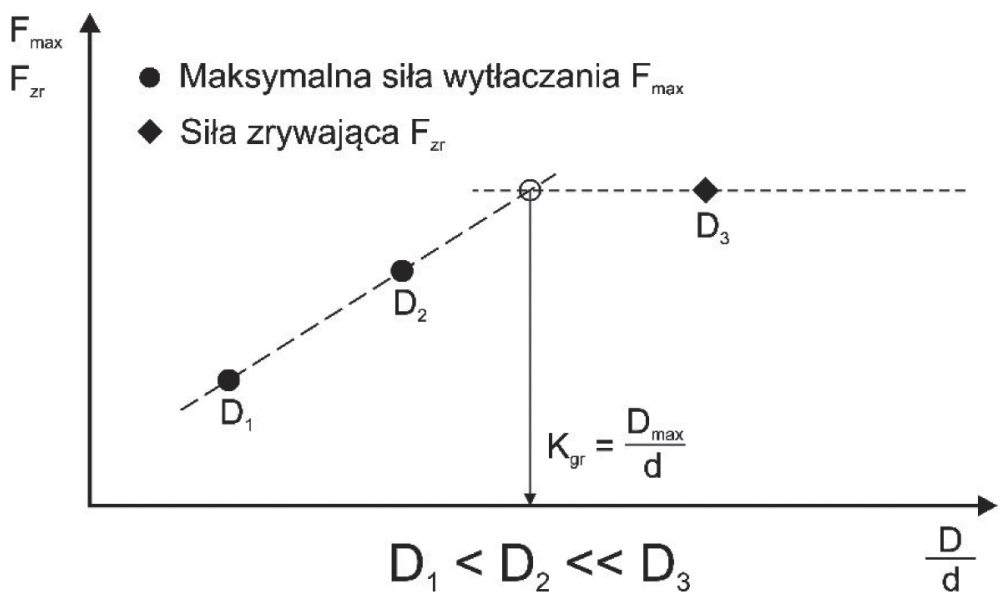

Rys. 2. Schemat wyznaczania granicznego stopnia wytłaczania w próbie miseczkowania AEG, przy założeniu $d=$ const

Podstawowym założeniem metody jest stałość średnicy wytłoczki dla danej grubości blachy. Ekstrapolacja wartości siły maksymalnej wytłaczania do wartości siły zrywającej pozwala na wyznaczenie przybliżonych wartości $K_{1 g r}$. Podobne wykresy wykonano z użyciem większej liczby punktów pomiarowych - zarówno siły maksymalnej wytłaczania, jak i siły zrywającej. Zastosowano również różne funkcje aproksymacji wyników. Do badań użyto krążków o średnicach od $38 \mathrm{~mm}$ do $80 \mathrm{~mm}$. Pozwoliło to na określenie maksymalnych wartości stopnia wytłaczania i porównanie ich z wartościami granicznymi, wyznaczonymi w próbie tłoczności metodą Swifta. Każdorazowo określano różnicę względną $\delta_{x}$ według zależności (2):

$$
\delta_{x}=\frac{x-x_{0}}{x_{0}} \cdot 100 \%
$$

gdzie:

$x$ - wartość wskaźnika z metody miseczkowania AEG,

$x_{0}$ - wartość wskaźnika z próby tłoczności Swifta.

\section{Wyniki badań i ich analiza}

\subsection{Próba tłoczności Swifta}

W tabeli 2 przedstawiono wyniki prób tłoczności Swifta. Plusami oznaczono wytłaczanie zakończone powodzeniem, a minusami zerwanie wytłoczek. W zależności od grubości blachy, uzyskano różne maksymalne wartości średnicy krąż̇ów (pogrubiony znak +), tym większe, im większa była grubość materiału. 
Tabela 2

Wyniki próby tłoczności metodą Swifta

\begin{tabular}{|c|c|c|c|}
\hline Średnica krążka $D[\mathrm{~mm}]$ & $g=1 \mathrm{~mm}$ & $g=0,8 \mathrm{~mm}$ & $g=0,5 \mathrm{~mm}$ \\
\hline 50 & + & + & + \\
\hline 51 & + & + & + \\
\hline 52 & + & + & + \\
\hline 53 & + & + & - \\
\hline 54 & + & + & - \\
\hline 55 & + & + & - \\
\hline 56 & + & - & - \\
\hline 57 & + & - & - \\
\hline 58 & + & - & - \\
\hline 59 & - & - & \\
\hline 60 & - & & \\
\hline
\end{tabular}

Na podstawie wyników z tabeli 2 wyznaczono minimalne wartości współczynnika wytłaczania oraz maksymalne wartości stopnia wytłaczania (tab. 3). Wraz ze wzrostem grubości względnej krążka graniczne przeformowanie rosło (rys. 3), co jest zgodne z teorią i praktyką.

\section{Tabela 3}

Wartości graniczne wskaźników, określone w próbie tłoczności Swifta dla różnych grubości blachy ze stopu aluminium EN AW-1050A H14

\begin{tabular}{|c|c|c|c|c|}
\hline$g[\mathrm{~mm}]$ & $D_{\max }[\mathrm{mm}]$ & $g / D_{\max } \cdot 100$ & $m_{1 g r}$ & $K_{1 g r}$ \\
\hline 1,0 & 58 & 1,724 & 0,552 & 1,813 \\
\hline 0,8 & 56 & 1,455 & 0,571 & 1,750 \\
\hline 0,5 & 53 & 0,943 & 0,604 & 1,656 \\
\hline
\end{tabular}

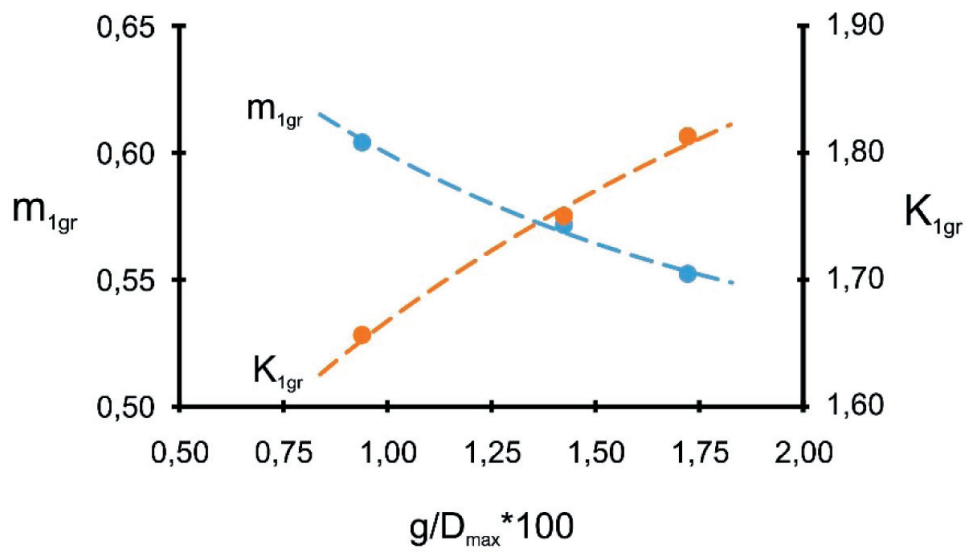

Rys. 3. Wartości granicznego współczynnika oraz stopnia wytłaczania w funkcji grubości względnej krążka (dla $D=D_{\max }$ ), wyznaczone w próbie tłoczności Swifta 


\subsection{Standardowa próba miseczkowania AEG}

$\mathrm{Na}$ podstawie wartości zmierzonych w próbie sił wykonano wykresy zależności maksymalnej siły wytłaczania oraz siły zrywającej w funkcji stosunku $D / d$ (rys. 4). Wyznaczone na ich podstawie wartości graniczne stopnia wytłaczania $K_{1 g r}$ odbiegają od wartości określonych na podstawie próby tłoczności Swifta dla danej grubości blachy (tab. 4). Względna różnica $\delta_{x}$ mieści się w przedziale 3,6-6,6\%. Pokazuje to, że w analizowanym przypadku wyniki standardowej metody miseczkowania AEG (dwa punkty pomiarowe maksymalnej siły wytłaczania: $2 x F_{\max }$; jeden punkt pomiarowy siły zrywającej: $1 x F_{z r}$ ) obarczone są pewnym błędem. Przy zastosowaniu wyznaczonych w ten sposób wartości granicznych wskaźników, zachodzi niebezpieczeństwo pękania wytłoczek podczas tłoczenia.
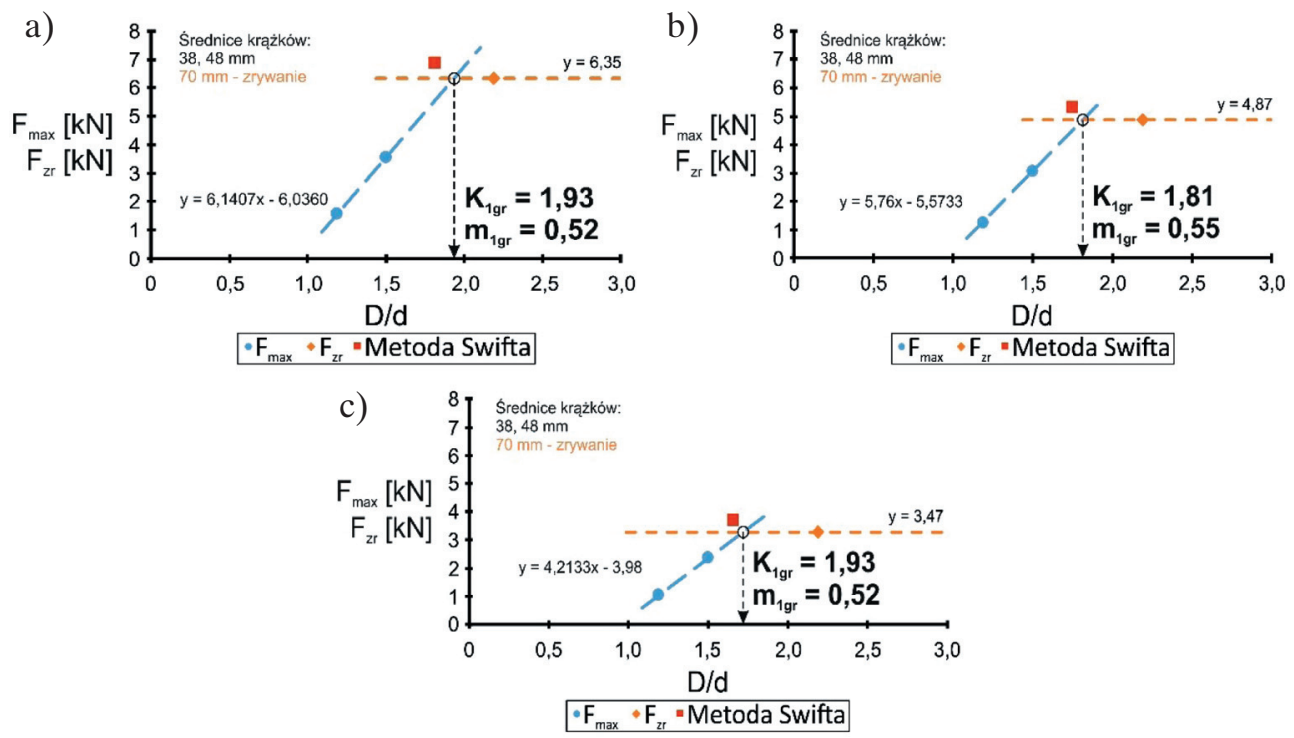

Rys. 4. Wykresy sił w procesie wytłaczania w funkcji $D / d$ dla blach o grubości 1,0 mm (a), $0,8 \mathrm{~mm}(\mathrm{~b})$ i $0,5 \mathrm{~mm}(\mathrm{c})$

Tabela 4

Wyniki standardowej próby miseczkowania AEG $\left(2 x F_{\max }, 1 x F_{z r}\right)$ dla blach o różnej grubości

\begin{tabular}{|c|c|c|c|}
\hline$g[\mathrm{~mm}]$ & $m_{1 g r}$ & $K_{1 g r}$ & $\delta_{x}[\%]$ \\
\hline 1,0 & 0,518 & 1,931 & 6,6 \\
\hline 0,8 & 0,551 & 1,814 & 3,6 \\
\hline 0,5 & 0,582 & 1,718 & 3,7 \\
\hline
\end{tabular}

Podczas wyznaczania względnej różnicy $\delta_{x}$ dla danej grubości blachy zastosowano wartości granicznego stopnia wytłaczania $K_{1 g r}$, określone na podstawie metody misecz- 
kowania AEG oraz próby tłoczności Swifta. Obliczone w ten sposób jej wartości (klasyczna metoda AEG) były dodatnie. W przypadku granicznego współczynnika wytłaczania $m_{1 g r}$ różnica $\delta_{x}$ byłaby co do wartości taka sama jak dla $K_{1 g r}$, lecz z przeciwnym znakiem. W analogiczny sposób w dalszej części pracy przeprowadzono analizę różnicy względnej $\delta_{x}$ granicznego stopnia wytłaczania.

\subsection{Wpływ liczby punktów pomiarowych maksymalnej siły wytłaczania na wynik próby miseczkowania AEG}

Wprowadzenie nieznacznych modyfikacji do metody miseczkowania AEG (zwiększenie liczby punktów pomiarowych $F_{\max }$ i/lub $F_{z r}$, sposób aproksymacji), które nie wpłyną istotnie na czas trwania oraz pracochłonność próby, może skutkować większą jej dokładnością. Podczas analizy wyników stwierdzono na przykład krzywoliniowy charakter ułożenia punktów pomiarowych maksymalnej siły wytłaczania (rys. 5), co sugeruje celowość zastosowania innych funkcji aproksymacji niż liniowa. Wszystko to może mieć wpływ na zbieżność wartości wskaźników uzyskanych w porównywanych próbach tłoczności.

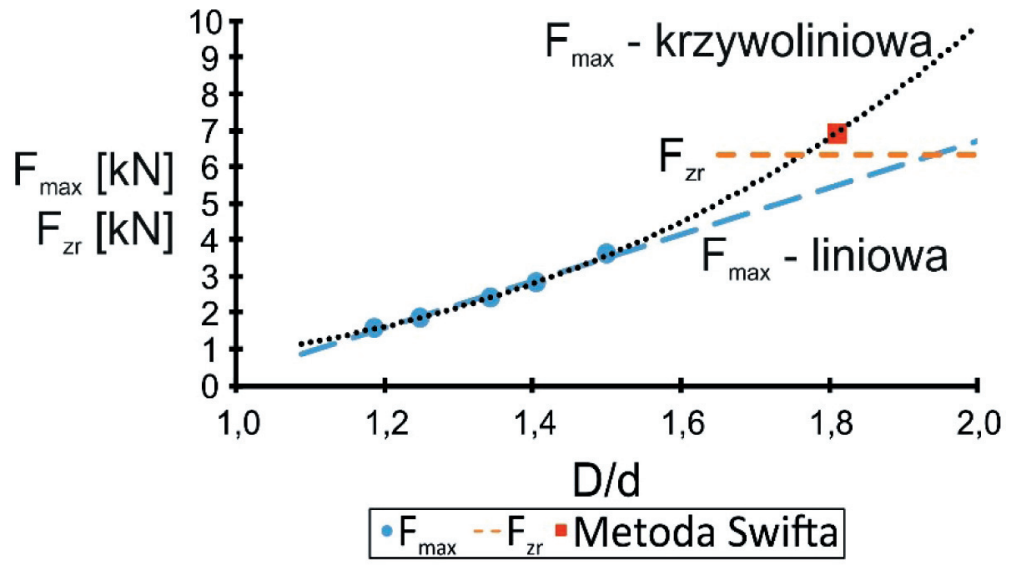

Rys. 5. Wykres maksymalnej siły wytłaczania w funkcji $D / d$ z zastosowaniem dwóch różnych podejść do aproksymacji wyników (liniowa, krzywoliniowa)

\subsubsection{Aproksymacja liniowa}

Zastosowanie większej liczby punktów pomiarowych maksymalnej siły wytłaczenia nie przyczyniło się do uzyskania wyników bliższych określonym metodą Swifta. Stwierdzono nieznaczną zmianę wartości wskaźników w stosunku do standardowego podejścia do metody miseczkowania AEG (tab. 5, rys. 6). Wartości dopuszczalnego stopnia 
wytłaczania nadal były zawyżone. Stwierdzono jednocześnie, że w przypadku cieńszych blach zbieżność wyników była większa (rys. 6). Względna różnica w $\delta_{x}$ dla grubości blachy równej $0,5 \mathrm{~mm}$ średnio wynosiła $3,1 \%$, przy $6,8 \%$ dla blachy o grubości $1,0 \mathrm{~mm}$.

\section{Tabela 5}

Wartości graniczne wskaźników tłoczności blach o różnej grubości dla różnych liczb pomiarów maksymalnej siły wytłaczania - aproksymacja liniowa $F_{\max }=f(D / d)$

\begin{tabular}{|c|c|c|c|c|c|c|}
\hline \multirow{2}{*}{$g[\mathrm{~mm}]$} & \multicolumn{2}{|c|}{ AEG $\left(2 x F_{\max }\right)$} & \multicolumn{2}{c|}{ AEG $\left(3 x F_{\max }\right)$} & \multicolumn{2}{c|}{ AEG $\left(5 x F_{\max }\right)$} \\
\cline { 2 - 7 } & $m_{1 g r}$ & $K_{1 g r}$ & $m_{1 g r}$ & $K_{1 g r}$ & $m_{1 g r}$ & $K_{1 g r}$ \\
\hline 1,0 & 0,518 & 1,931 & 0,515 & 1,940 & 0,514 & 1,945 \\
\hline 0,8 & 0,551 & 1,814 & 0,549 & 1,821 & 0,554 & 1,806 \\
\hline 0,5 & 0,582 & 1,718 & 0,584 & 1,711 & 0,589 & 1,697 \\
\hline
\end{tabular}

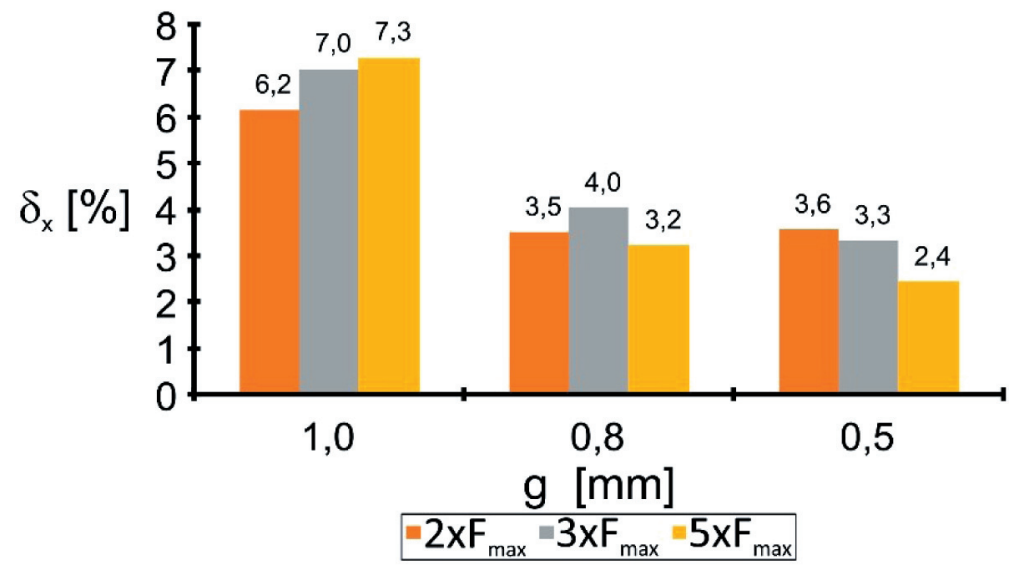

Rys. 6. Względna różnica $\delta_{x}$ granicznego stopnia wytłaczania $K_{1 g r}$ w funkcji grubości blachy $g$ dla różnej liczby punktów pomiarowych maksymalnej siły ciągnienia

Charakter zmiany wartości $\delta_{x}$ w funkcji liczby pomiarów maksymalnej siły wytłaczania był różny dla różnych grubości blachy. W przypadku blachy o grubości $1,0 \mathrm{~mm}$ różnica względna rosła wraz z liczbą punktów pomiaru. Natomiast dla $g=0,5 \mathrm{~mm}$ wartość $\delta_{x}$ malała. Jednakże dla danej grubości blachy różnice wyznaczonych wartości $\delta_{x}$ były niewielkie i mieściły się w granicach błędu.

\subsubsection{Aproksymacja krzywoliniowa}

Analizie poddano dwa rodzaje funkcji aproksymacji krzywoliniowych: potęgową i wykładniczą. Na rysunku 7 przedstawiono przykładowe wykresy maksymalnej siły wytłaczania w funkcji $D / d$ dla trzech i pięciu punktów pomiarowych oraz różnych funkcji 
aproksymacji. Wyznaczone w ten sposób wartości stopni wytłaczania $K_{1 g r}$ dla analizowanych grubości blachy przedstawiono w tabeli 6 . Były niższe od wyznaczonych za pomoca próby tłoczności Swifta (tab. 3) i w bezpiecznym zakresie wartości.
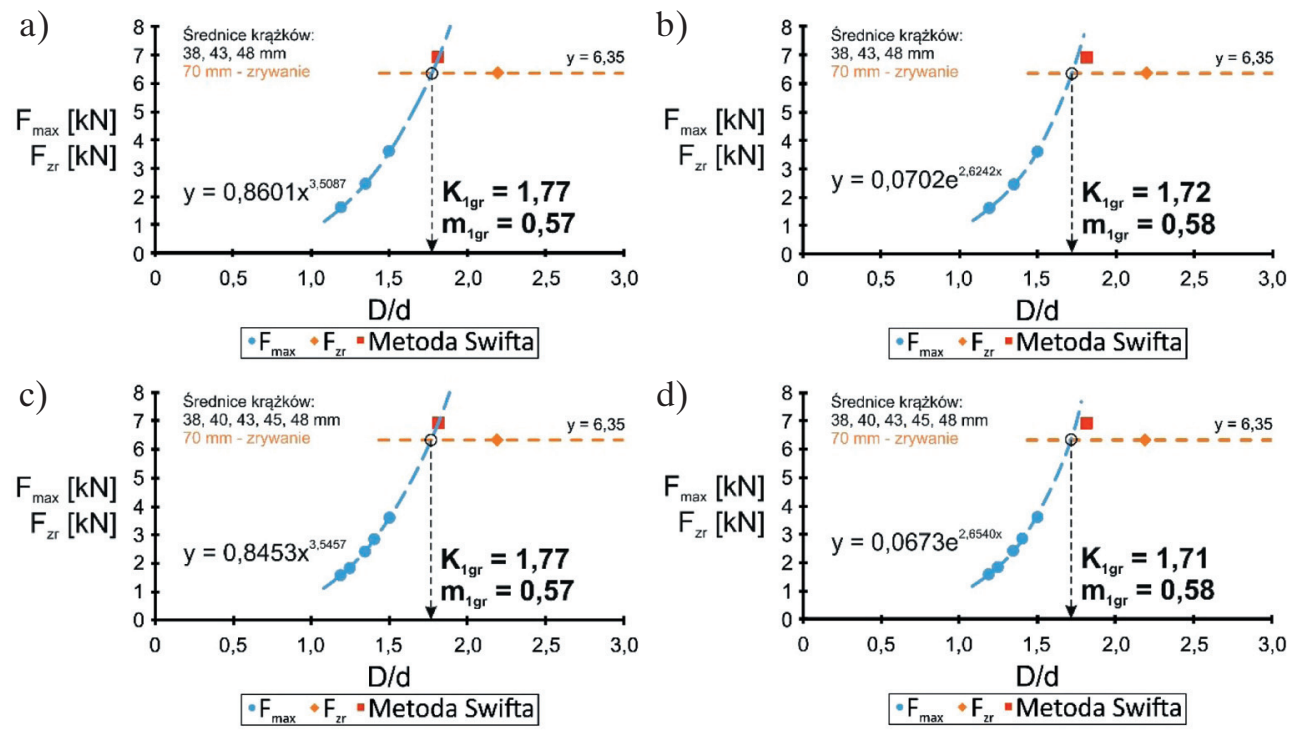

Rys. 7. Wykres sił w procesie wytłaczania w funkcji $D / d$ dla blach o grubości $1 \mathrm{~mm}$ dla różnej liczby punktów pomiarowych i funkcji aproksymacji: 3 punkty aproksymowane funkcją potęgową (a) i wykładniczą (b), 5 punktów aproksymowanych funkcją potęgową (c) i wykładniczą (d)

\section{Tabela 6}

Wartości graniczne wskaźników wytłaczania w zależności od liczby punktów pomiarowych $F_{\max }$ oraz ich funkcji aproksymacji

\begin{tabular}{|c|c|c|c|c|c|c|c|c|c|c|c|c|}
\hline \multirow{3}{*}{$\begin{array}{c}g \\
{[\mathrm{~mm}]}\end{array}$} & \multicolumn{3}{|c|}{ Potęgowa } & \multicolumn{5}{c|}{ Wykładnicza } \\
\cline { 2 - 14 } & \multicolumn{3}{|c|}{$3 x F_{\max }$} & \multicolumn{3}{c|}{$5 x F_{\max }$} & \multicolumn{3}{c|}{$3 x F_{\max }$} & \multicolumn{3}{c|}{$5 x F_{\max }$} \\
\cline { 2 - 13 } & $m_{1 g r}$ & $K_{1 g r}$ & $\begin{array}{c}\delta_{x} \\
{[\%]}\end{array}$ & $m_{1 g r}$ & $K_{1 g r}$ & $\begin{array}{c}\delta_{x} \\
{[\%]}\end{array}$ & $m_{1 g r}$ & $K_{1 g r}$ & $\begin{array}{c}\delta_{x} \\
{[\%]}\end{array}$ & $m_{1 g r}$ & $K_{1 g r}$ & $\begin{array}{c}\delta_{x} \\
{[\%]}\end{array}$ \\
\hline 1,0 & 0,564 & 1,774 & $-2,1$ & 0,566 & 1,766 & $-2,6$ & 0,583 & 1,716 & $-5,3$ & 0,584 & 1,713 & $-5,5$ \\
\hline 0,8 & 0,584 & 1,714 & $-2,1$ & 0,589 & 1,697 & $-3,0$ & 0,603 & 1,658 & $-5,3$ & 0,606 & 1,650 & $-5,7$ \\
\hline 0,5 & 0,614 & 1,629 & $-1,6$ & 0,620 & 1,613 & $-2,6$ & 0,629 & 1,589 & $-4,1$ & 0,632 & 1,582 & $-4,5$ \\
\hline
\end{tabular}

Dla danego rodzaju zastosowanej krzywoliniowej funkcji aproksymacji wartości $K_{1 g r}$ w przypadku trzech i pięciu punktów pomiarowych maksymalnej siły wytłaczania były do siebie bardzo zbliżone. Można zatem uznać, że do określenia ich wartości wystarczy 
mniejsza liczba pomiarów $F_{\max }$. Jednocześnie niższą wartość różnicy $\delta_{x}$, określanej względem wartości z próby Swifta, uzyskano w przypadku zastosowania funkcji potęgowej (rys. 8).

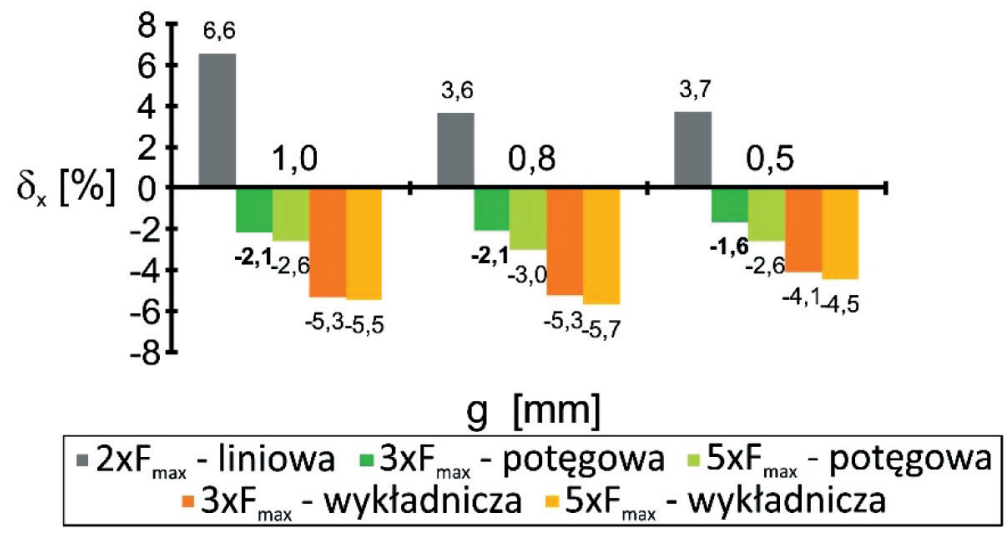

Rys. 8. Zależność dokładności pomiaru granicznego stopnia wytłaczania $K_{1 g r}$ od liczby punktów pomiarowych maksymalnej siły tłoczenia oraz od funkcji aproksymacji dla różnej grubości blachy

Zastosowanie trzech pomiarów maksymalnej siły wytłaczania oraz potęgowej funkcji aproksymującej dało najkorzystniejsze wyniki spośród analizowanych opcji modyfikacji próby miseczkowania AEG. Wartości $\delta_{x}$ uzyskane tą metodą zostały obniżone do poziomu $-2,1 \%$ dla blach o grubościach $1,0 \mathrm{~mm}$ i $0,8 \mathrm{~mm}$ oraz do $-1,6 \%$ dla najcieńszych blach.

\subsection{Wpływ liczby punktów pomiarowych siły zrywającej na wynik próby miseczkowania AEG}

W przeciwieństwie do wyników uzyskanych przez innych autorów (Reddy i in 2014, 2020b) w niniejszej pracy stwierdzono spadek wartości siły zrywającej wraz ze wzrostem średnicy krążka (rys. 9). Uwzględnienie liniowej zmiany wartości siły zrywającej w funkcji $D / d$ spowodowało przesunięcie punktu przecięcia linii wykresów w prawo. W konsekwencji, wartości graniczne stopnia wytłaczania prawie pokrywały się z wynikami próby Swifta (rys. 10). Efekt ten zaobserwowano dla wszystkich analizowanych grubości blachy.

Zaproponowana zmodyfikowana metoda miseczkowania AEG (aproksymacja funkcją potęgową trzech punktów maksymalnej siły wytłaczania oraz funkcją liniową dwóch punktów siły zrywającej) dała wartości $K_{1 g r}$ zdecydowanie bliższe wyznaczonym w próbie tłoczności Swifta. Względna różnica $\delta_{x}$ nie przekraczała $\pm 1 \%$. W porównaniu ze standardową metodą AEG była 6-krotnie do ponad 8-krotnie niższa (tab. 7). 
W przypadku blach o grubościach równych $0,8 \mathrm{~mm}$ oraz $1,0 \mathrm{~mm}$ dopuszczalne wartości stopnia wytłaczania były nieco niższe od uzyskanych za pomocą metody Swifta. Natomiast dla najmniejszej z badanych grubości blachy $(0,5 \mathrm{~mm})$ uzyskana wartość $K_{1 g r}$ była minimalnie wyższa (o około 0,01). Tak mała wartość przeszacowania nie wpływa na praktyczną przydatność uzyskanych wyników.

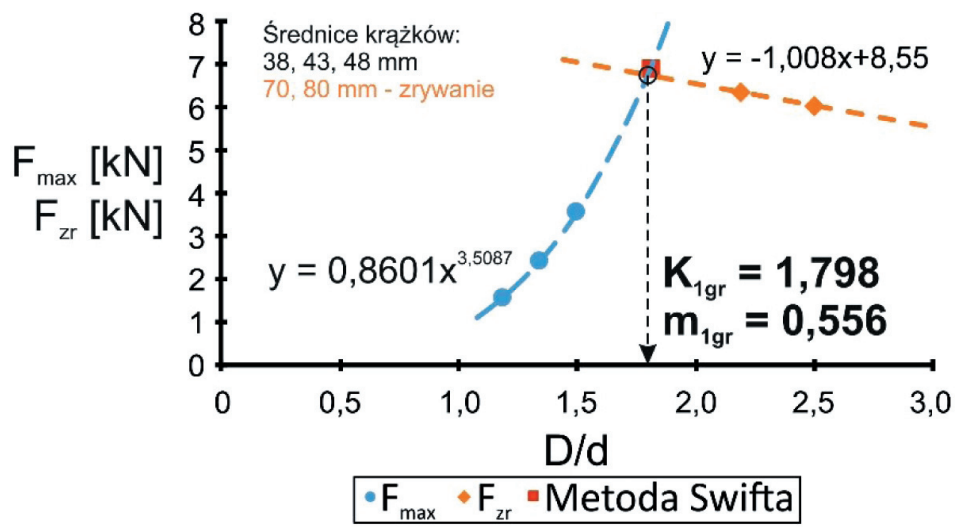

Rys. 9. Wykres sił w procesie wytłaczania w funkcji $D / d$ dla blach o grubości $1 \mathrm{~mm}$, przedstawiający ideę zmodyfikowanej metody AEG $\left(3 x F_{\max }, 2 x F_{z r}\right)$
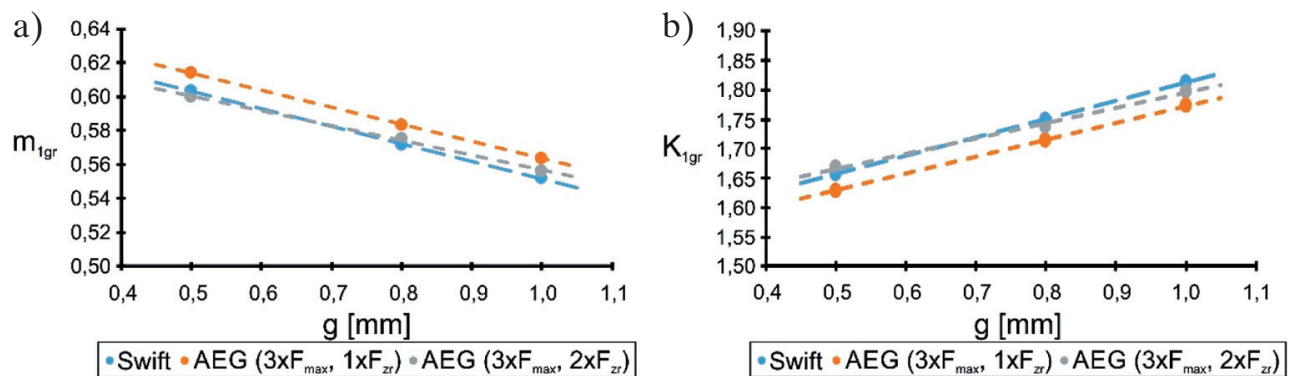

Rys. 10. Porównanie wartości $m_{1 g r}(\mathrm{a})$ oraz $K_{1 g r}$ (b) w zależności od metody ich wyznaczania

Tabela 7

Wartości dopuszczalnego współczynnika i stopnia wytłaczania w zależności od zastosowanej metody w próbie AEG badania tłoczności blach

\begin{tabular}{|c|c|c|c|c|c|c|}
\hline \multirow{2}{*}{$g[\mathrm{~mm}]$} & \multicolumn{3}{|c|}{ AEG standardowa } & \multicolumn{3}{c|}{ AEG zmodyfikowana } \\
& \multicolumn{2}{|c|}{$\left(2 x F_{\max }-\right.$ liniowa, $\left.1 x F_{\max }\right)$} & $\left(3 x F_{\max }-\right.$ potegowa, $2 x F_{z r}-$ linowa $)$ \\
\cline { 2 - 7 } & $m_{1 g r}$ & $K_{1 g r}$ & $\delta_{x}[\%]$ & $m_{1 g r}$ & $K_{1 g r}$ & $\delta_{x}[\%]$ \\
\hline 1,0 & 0,518 & 1,931 & 6,6 & 0,556 & 1,798 & $-0,8$ \\
\hline 0,8 & 0,551 & 1,814 & 3,6 & 0,575 & 1,739 & $-0,6$ \\
\hline 0,5 & 0,582 & 1,718 & 3,7 & 0,600 & 1,667 & 0,6 \\
\hline
\end{tabular}




\section{Wnioski}

W pracy poddano analizie wpływ liczby punktów pomiarowych maksymalnej siły wytłaczania i siły zrywającej oraz rodzaju funkcji aproksymującej na wartość granicznego współczynnika i stopnia wytłaczania. Wartości tych wskaźników określono na podstawie metody miseczkowania AEG - standardowej i zmodyfikowanej - i porównano z wynikami próby tłoczności metodą Swifta.

Na podstawie uzyskanych wyników i ich analizy sformułowano następujące wnioski:

1. Niezależnie od grubości blachy ze stopu aluminium EN AW-1050A H14 wartości wskaźników uzyskane standardową metodą AEG znacznie różnią się od wartości wyznaczonych metodą Swifta. Zastosowanie większej liczby punktów pomiarowych, przy jednoczesnym przybliżaniu wyników za pomocą funkcji liniowej nie poprawia dokładności metody. Wartości minimalne dopuszczalnych współczynników wytłaczania są niedoszacowane, a maksymalne dopuszczalne stopnie wytłaczania przeszacowane. Zastosowanie otrzymanych w ten sposób wskaźników w procesach technologicznych może skutkować pękaniem blachy podczas wytłaczania.

2. Modyfikacja metody AEG polegająca na zmianie funkcji aproksymacji punktów siły maksymalnej z liniowej na potęgową (na podstawie trzech punktów pomiarowych) oraz zastosowanie aproksymacji liniowej dla co najmniej dwóch punktów pomiarowych siły zrywającej powoduje, że wyznaczone wartości wskaźników granicznych uzyskane tą metodą są bardzo zbliżone do określonych na w próbie tłoczności Swifta. Nakład pracy potrzebny do ich określenia jest przy tym nadal zdecydowanie mniejszy.

Praca została sfinansowana z subwencji badawczej WMN AGH nr 16.16.180.006.

\section{Literatura}

Bruschi S., Altan T., Banabic D., Bariani P.F., Brosius A., Cao J., Ghiotti A., Khraisheh M., Merklein M., Tekkaya A.E., 2014, Testing and modelling of material behaviour and formability in sheet metal forming, CIRP Annals - Manufacturing Technology, vol. 63, no. 2, s. 727-749. https://doi.org/10.1016/j.cirp.2014.05.005.

Chen J., Qian J., Li S., 2011, Numerical Simulation and Experimental Study of Limit Drawing Ratio of Steel Sheets, Advanced Materials Research, vol. 189-193, s. 2539-2542. https://doi.org/10.4028/www.scientific.net/AMR.189-193.2539.

Erbel S., Kuczyński K., Marciniak Z., 1986, Obróbka plastyczna, Polskie Wydawnictwo Naukowe, Warszawa.

Fisher G.R., 1927, Prüfverfahren zur Wertung von Ziehblechen, AEG-Mitt, s. 419-420. 
INOP-Z/201-12-78: Tłoczność blach - Próba tłoczności metoda Swifta.

Kandil A., 2003, An experimental study of hydroforming deep drawing, Journal of Materials Processing Technology, vol. 134, no. 1, s. 70-80. https://doi.org/10.1016/S09240136(02)00922-6.

Kumar R.U., 2020, Comparative study on limiting drawing ratio of Al 1100 and pure copper, Journal of Engineering Sciences, vol. 52, no. 1, s. 53-56.

Kumar R.U., Reddy G.C., 2014, Analysis of Swift cup drawing test, International Journal of Application or Innovation in Engineering \& Management, vol. 3, no. 10, s. 104-108.

Marciniak Z., 1961, Mechanika procesów tłoczenia blach, Wydawnictwa Naukowo-Techniczne, Warszawa.

Marciniak Z., 1989, Wpływ plastycznych właściwości blachy na jej tłoczność, Obróbka Plastyczna Metali, t. 4, s. 5-11.

Morawiecki M., Sadok L., Wosiek E., 1986, Przeróbka plastyczna. Podstawy teoretyczne, Wydawnictwo „Śląsk”, Katowice.

Muzykiewicz W., 2013, Odksztatcalność blach perforowanych, Wydawnictwo Naukowe AKAPIT, Kraków.

Muzykiewicz W., Rękas A., 2007, Badania jednooperacyjnego tłoczenia blachy bimetalowej $\mathrm{Cu} / \mathrm{Al}$, Rudy i Metale Nieżelazne, R. 52, nr 1, s. 18-22.

Muzykiewicz W., Rękas A., Kosmalski G., 2006, Badania walidacyjne blachy w gatunku 6082 w stanie „0” pod kątem jej zastosowań do procesów tłoczenia, Rudy i Metale Nieżelazne, R. 51, nr 7, s. 422-427.

Nghishiyeleke E.T., Mashingaidze M.M., Ogunmokun A.A., 2018, Formability characterization of aluminium AA6082-O sheet metal by uniaxial tension and Erichsen cupping tests, International Journal of Engineering \& Technology, vol. 7, no. 4, s. 6768-6777. https://doi.org/10.14419/ijet.v7i4.23870.

Reddy A.C.S., Rajesham S., Reddy P.R., 2014, Evaluation of Limiting Drawing Ratio (LDR) in Deep Drawing by Rapid Determination Method, International Journal of Current Engineering and Technology, vol. 4, no. 2, s. 757-762.

Reddy A.C.S., Rajesham S., Reddy P.R., Uamaheswar A.C., 2020a, Formability: A review on different sheet metal tests for formability, AIP Conference Proceedings, vol. 2269, 030026. https://doi.org/10.1063/5.0019536.

Reddy A.C.S., Rajesham S., Mahender T., 2020b, Experimental and Simulation Study in Deep Drawing of Circular Cups for Determination of LDR, [w:] Satapathy S., Raju K., Molugaram K., Krishnaiah A., Tsihrintzis G. (eds.), International Conference on Emerging Trends in Engineering (ICETE): Emerging Trends in Smart Modelling Systems and Design, Learning and Analytics in Intelligent Systems, vol. 2, Springer, Cham, s. 533-541.

Romanowski W.P., 1976, Poradnik obróbki plastycznej na zimno, Wydawnictwa Naukowo-Techniczne, Warszawa. 
Singh Ch.P., Agnihotri G., 2015, Study of deep drawing process parameters: a review, International Journal of Scientific and Research Publications, vol. 5, no. 2, s. 1-15.

Spišák E., Majerníková J., Kaščák L., 2016, Formability of thin sheets from aluminum alloys, Advances in Science and Technology Research Journal, vol. 10, no. 30, s. 248-263. https://doi.org/10.12913/22998624/65759.

Swift H.W., 1952, Plastic instability under plane stress, Journal of the Mechanics and Physics of Solids, vol. 1, s. 1-18. https://doi.org/10.1016/0022-5096(52)90002-1.

Turno A., 1971, Próba tłoczności blach metoda wyttaczania miseczki wg Swifta, Obróbka Plastyczna, t. 10, z. 1, s. 63-70.

Wang W., He C., Zhao Z., Wei X., 2011, The limit drawing ratio and formability prediction of advanced high strength dual-phase steels, Materials and Design, vol. 32, s. 3320-3327. https://doi.org/10.1016/j.matdes.2011.02.021.

Youssef H.A., El-Hofy H.A., Ahmed M.H., 2011, Manufacturing Technology. Materials, Processes, and Equipment, CRC Press. 